\title{
Monitoring Variabilitas Proses pada Kualitas Semen dengan Diagram Kendali Multivariate Exponentially Weighted Moving Covariance Matrix (MEWMC) based on Regression Adjusted Variables (Studi Kasus PT "X”)
}

\author{
Marita Qori'atunnadyah dan Wibawati \\ Departemen Statistika, Fakultas Sains dan Analitika Data, \\ Institut Teknologi Sepuluh Nopember (ITS) \\ Jl. Arief Rahman Hakim, Surabaya 60111 Indonesia \\ e-mail:wibawati@statistika.its.ac.id
}

\begin{abstract}
Abstrak - PT "X" merupakan Badan Usaha yang bergerak pada bidang pembuatan semen. Secara umum, kualitas semen ditentukan oleh kuat tekan semen yang diukur pada hari ke-3, ke-7 dan ke-28. Sementara itu, kuat tekan semen dipengaruhi oleh beberapa variabel yang merupakan komposisi kimia dan sifat fisika dari semen, diantaranya: $\mathrm{SiO}_{2}, \mathrm{Al}_{2} \mathrm{O}_{3}, \mathrm{Fe}_{2} \mathrm{O}_{3}, \mathrm{CaO}$, $\mathrm{MgO}, \mathrm{SO}_{3}, \mathrm{C}_{3} \mathrm{~S}, \mathrm{C}_{2} \mathrm{~S}, \mathrm{C}_{3} \mathrm{~A}, \mathrm{C}_{4} \mathrm{AF}, \mathrm{FCaO}, \mathrm{LOI}, \mathrm{R45}$, dan Blaine. Dalam penelitian ini digunakan analisis faktor untuk mengetahui variabel yang berpengaruh secara dominan terhadap kuat tekan semen dan diperoleh variabel $\mathrm{Al}_{2} \mathrm{O}_{3}, \mathrm{Fe}_{2} \mathrm{O}_{3}, \mathrm{C}_{3} \mathrm{~A}$, LOI, dan Blaine. Selanjutnya, dilakukan pengendalian variabilitas proses menggunakan diagram kendali MEWMC based on Regression Adjusted pada variabel hasil analisis faktor. Pada fase dua, nilai pembobot optimum yang digunakan yaitu $\lambda=0,1$ dan didapatkan hasil bahwa telah terkendali secara statistik atau tidak terjadi pergeseran proses.
\end{abstract}

Kata Kunci - Analisis Faktor, Kuat Tekan Semen, Multivariate Exponentially Weighted Moving Covariance Matrix (MEWMC), Regression Adjusted.

\section{PENDAHULUAN}

$\mathrm{P}$ embangunan infrastruktur yang maksimal dihasilkan dari bahan baku yang berkualitas. Salah satu bahan baku yang digunakan dalam pembangunan adalah semen. PT " $X$ " merupakan badan usaha yang bergerak pada bidang pembuatan semen. Tingginya permintaan akan kebutuhan semen mendorong PT "X" untuk selalu meningkatkan kualitas sesuai standar yang telah ditetapkan. Proses produksi semen memiliki lima tahapan diantaranya proses penyiapan bahan baku, proses pengolahan bahan, proses pembakaran, proses penggilingan akhir serta proses pengemasan [1]. Kualitas semen ditentukan oleh kuat tekan semen yang berada pada tahap penggilingan akhir (finish mill). Kuat tekan semen adalah kemampuan semen dalam menerima tekanan. Apabila kuat tekan semen tinggi, maka komponen yang terbuat dari semen tersebut akan semakin kokoh dan kuat untuk menopang beban berat sehingga tidak mudah rusak. Kuat tekan semen dibedakan menjadi tiga yaitu kuat tekan semen yang diukur pada hari ke-3, ke-7 dan ke-28. Ketiga variabel yang merupakan variabel respon ini saling berhubungan, dimana semakin lama usia semen maka kuat tekannya akan semakin tinggi. Oleh karena itu, sangat penting dilakukan pengujian kualitas di tahap penggilingan akhir sebelum semen masuk ke tahap pengemasan. Sementara itu, kuat tekan semen dipengaruhi oleh empat belas variabel yang merupakan variabel prediktor yaitu komposisi kimia dan sifat fisika dari semen. Komposisi kimia di dalam semen adalah $\mathrm{SiO}_{2}, \mathrm{Al}_{2} \mathrm{O}_{3}$, $\mathrm{Fe}_{2} \mathrm{O}_{3}, \mathrm{CaO}, \mathrm{MgO}, \mathrm{SO}_{3}, \mathrm{C}_{3} \mathrm{~S}, \mathrm{C}_{2} \mathrm{~S}, \mathrm{C}_{3} \mathrm{~A}, \mathrm{C}_{4} \mathrm{AF}, \mathrm{FCaO}$, LOI.
Sedangkan sifat fisika dari semen antara lain Blaine dan Residu 45 Mikron.

Penelitian sebelumnya yang berkaitan dengan kualitas semen telah dilakukan dengan menggunakan diagram kendali $I-\overline{M R}$ didapatkan kesimpulan bahwa dari keempat variabel utama penyusun Semen OPC tidak ada satu pun senyawa dengan proses terkendali. Pada pengamatan dengan menggunakan diagram kendali multivariat, Generalized Variance dan $\mathrm{T}^{2}$ Hotelling didapatkan hasil out of control pada fase kedua sehingga diketahui bahwa proses belum terkendali secara statistik [2]. Kemudian penelitian yang juga berkaitan dengan kualitas semen dan Regression Adjusted menghasilkan pada fase satu yaitu periode bulan Januari 2014 - Juni 2014, variabilitas dan mean proses produksi dengan menggunakan diagram kontrol MEWMV dan MEWMA telah terkendali secara statistik [3].

Pada penelitian sebelumnya dapat diketahui bahwa proses monitoring variabilitas telah dilakukan menggunakan diagram kendali Generalized Variance dan MEWMV. Oleh karena itu, pada penelitian ini dipilih diagram kendali Multivariate Exponentially Weighted Moving Covariance Matrix (MEWMC) karena diagram kendali ini efektif memonitor perubahan dalam matriks kovarians, dimana diagram kendali ini unggul ketika ada dalam kasus di mana varians atau korelasi mengalami perubahan. Selain itu, diagram kendali MEWMC robust terhadap distribusi tidak normal multivariat dan adanya autokorelasi. Karena kuat tekan semen dipengaruhi oleh beberapa variabel yang merupakan komposisi kimia dan sifat fisika dari semen maka untuk kasus ini digunakan diagram kendali dengan pendekatan Regression Adjusted Variables. Pada penelitian ini pengendalian variabilitas dilakukan menggunakan variabel yang berpengaruh dominan terhadap kuat tekan semen. Oleh karena itu, digunakan analisis faktor untuk mengetahui variabel manakah yang berpengaruh dominan terhadap kuat tekan semen secara statistik yang kemudian dapat dibandingkan dengan keadaan secara teknis di lapangan. Apabila terjadi perbedaan di antara keduanya maka penyelidikan proses dan tindakan korektif dapat dilakukan untuk mengetahui penyebabnya. Selanjutnya, dilakukan proses monitoring variabilitas menggunakan diagram kendali MEWMC based on Regression Adjusted pada variabel hasil analisis faktor. 


\section{TINJAUAN PUSTAKA}

\section{A. Uji Normal Multivariat}

Uji normal multivariat dapat dilakukan dengan menggunakan uji koefisien korelasi. Berikut merupakan uji koefisien korelasi untuk melihat apakah data memenuhi asumsi distribusi normal multivariat atau tidak. Hipotesis :

$\mathrm{H}_{0} \quad$ : Data berdistribusi normal multivariat

$\mathrm{H}_{1} \quad$ : Data tidak berdistribusi normal multivariat Statistik uji :

$$
r_{q}=\frac{\sum_{j=1}^{n}\left(x_{(j)}-\bar{x}\right)\left(q_{(j)}-\bar{q}\right)}{\sqrt{\sum_{j=1}^{n}\left(x_{(j)}-\bar{x}\right)^{2}} \sqrt{\sum_{j=1}^{n}\left(q_{(j)}-\bar{q}\right)^{2}}}
$$

dimana $q_{j}=\frac{j-\frac{1}{2}}{n}, j=1,2, \ldots, n$.

Daerah Kritis:

Tolak $\mathrm{H}_{0}$ jika $r_{q}<r_{(\alpha, n)}$.

Jika hasil dari statistik uji memiliki hasil yang kurang dari tabel normal probabilitas koefisien korelasi $r_{(\alpha, n)}$, maka dapat disimpulkan bahwa data tidak berdistribusi normal multivariat, begitu pun sebaliknya [4].

\section{B. Uji Kecukupan Data}

Identifikasi kecukupan data bertujuan untuk mengetahui kelayakan data dalam melakukan analisis faktor. Pengujian dilakukan menggunakan uji Kaiser-Meyer-Olkin (KMO) dengan hipotesis sebagai berikut.

Hipotesis :

$\mathrm{H}_{0} \quad$ : Data memenuhi asumsi kecukupan data

$\mathrm{H}_{1} \quad$ : Data tidak memenuhi asumsi kecukupan data Statistik uji :

$$
K M O=\frac{\sum_{i=1}^{p} \sum_{j=1}^{p} r_{i j}^{2}}{\sum_{i=1}^{p} \sum_{j=1}^{p} r_{i j}^{2}+\sum_{i=1}^{p} \sum_{j=1}^{p} a_{i j}^{2}}
$$

Jika nilai KMO lebih besar dari 0,5 maka memenuhi asumsi kecukupan data yang berarti terdapat korelasi parsial yang cukup pada data untuk dilakukan analisis faktor. Apabila nilai KMO kurang dari 0,5 maka yang harus dilakukan adalah mengumpulkan lebih banyak data atau memilih variabel yang akan dimasukkan. Measures of Sampling Adequancy (MSA) atau ukuran kecukupan sampling, merupakan indeks yang dimiliki setiap variabel yang menjelaskan apakah sampel yang diambil dalam penelitian cukup untuk membuat variabelvariabel yang ada saling terkait secara parsial. Nilai MSA berkisar antara 0 sampai 1 . Hanya variabel yang memiliki ukuran kecukupan sampling (MSA) diatas $(>0.5)$ yang akan diterima dan dimasukkan kedalam analisis [5].

\section{Uji Bartlett}

Uji Bartlett bertujuan untuk mengetahui apakah terdapat homogenitas varians antar variabel dalam kasus multivariat. Jika variabel $X_{1}, X_{2}, \ldots, X_{p}$ bersifat saling bebas, maka matriks korelasi antar variabel sama dengan matriks identitas. Untuk menguji kebebasan antarvariabel, dapat dilakukan uji Bartlett sphericity. Uji Bartlett sphericity dapat dinyatakan dalam hipotesis sebagai berikut.

\section{$\mathrm{H}_{0}: \mathbf{R}=\mathbf{I}$ (tidak terdapat korelasi antar variabel) \\ $\mathrm{H}_{1}: \mathbf{R} \neq \mathbf{I}$ (terdapat korelasi antar variabel)}

Statistik Uji :

$$
\chi_{\text {hitung }}^{2}=-\left[n-1-\frac{2 p+5}{6}\right] \ln |\mathbf{R}|,
$$

dimana $\mathrm{n}$ adalah jumlah observasi, sedangkan $\mathrm{p}$ adalah jumlah variabel, dan $\mathrm{R}$ adalah matriks korelasi dari masing-masing variabel, serta $\chi_{\left(\alpha ; \frac{1}{2} p(p-1)\right)}^{2}$ adalah nilai distribusi chi-square. Jika ditetapkan tingkat signifikansi $\alpha$ sebesar 0,05 , maka $\mathrm{H}_{0}$ ditolak jika nilai $\chi_{\text {hitung }}^{2}>\chi_{\left(\alpha ; \frac{1}{2} p(p-1)\right)}^{2}$ dan dapat disimpulkan bahwa matriks korelasi tidak sama dengan matriks identitas atau terdapat korelasi antar variabel [6].

\section{Analisis Faktor}

Tujuan utama dari analisis faktor adalah untuk mendeskripsikan hubungan antar kovarians dari banyak variabel dalam kuantitas random yang disebut faktor. Variabel random teramati $X$ dengan $p$ komponen, memiliki rata-rata $\mu$ dan matriks kovarians $\boldsymbol{\Sigma}$. Model faktor dari $X$ yang merupakan kombinasi linier beberapa variabel saling bebas yang tidak teramati adalah $F_{1}, F_{2}, \ldots, F_{m}$ yang disebut common factors dan ditambahkan dengan $\varepsilon_{1}, \varepsilon_{2}, \ldots, \varepsilon_{p}$ yang disebut specific factor, sehingga secara khusus dapat ditulis sebagai berikut

$$
\begin{gathered}
X_{1}-\mu_{1}=l_{11} F_{1}+l_{12} F_{2}+\ldots+l_{1 m} F_{m}+\varepsilon_{1} \\
X_{2}-\mu_{2}=l_{21} F_{1}+l_{22} F_{2}+\ldots+l_{2 m} F_{m}+\varepsilon_{2}, \\
\vdots \\
X_{p}-\mu_{p}=l_{p 1} F_{1}+l_{p 2} F_{2}+\ldots+l_{p m} F_{m}+\varepsilon_{p}
\end{gathered}
$$

atau dapat ditulis dalam notasi matriks sebagai berikut.

$$
\mathbf{X}_{p \times 1}-\boldsymbol{\mu}_{(p \times 1)}=\mathbf{l}_{(p \times m)} \mathbf{F}_{(m \times 1)}+\boldsymbol{\varepsilon}_{p \times 1} .
$$

Keterangan :

$\mu_{i}=$ rata-rata variabel $i$

$\varepsilon_{i}=$ faktor spesifik ke- $i$

$F_{i}=$ common faktor ke- $j$

$\ell_{i j}=$ loading dari variabel ke- $i$ pada faktor ke- $j$

Metode penentuan banyak faktor yang terbentuk didasarkan pada hal-hal berikut.

1. Banyaknya fakor dipilih sesuai dengan banyaknya eigenvalue yang lebih besar dari satu. Dikarenakan nilai eigenvalue yang berada dibawah 1 atau mendekati 0 biasanya tidak dipergunakan sebab dalam menerangkan keragaman data sangat kecil.

2. Jumlah faktor yang terbentuk adalah yang mampu memberikan kumulatif persen varians $80 \%-90 \%$.

3. Melalui scree plot, jika garis yang terbentuk pada scree plot memiliki range yang cukup besar maka jumlah faktor yang terbentuk sejumah garis tersebut.

Langkah selanjutnya setelah penentuan banyaknya faktor yang terbentuk yaitu mengelompokkan variabel ke dalam faktor menggunakan rotated component matrix. Hasil dari ekstraksi faktor dalam matriks faktor mengidentifikasikan hubungan antar faktor dan variabel individual, namun dalam faktor-faktor tersebut banyak variabel yang berkorelasi sehingga sulit diinterpretasikan. Melalui rotasi faktor matriks, faktor matriks ditransformasikan ke dalam matriks yang lebih 
sederhana sehingga mudah diinterpretasikan. Rotasi faktor menggunakan prosedur varimax. Rotasi varimax menghendaki varians yang maksimum dalam matriks faktor yang terbentuk, sehingga menjadikan setiap peubah asal hanya akan mempunyai korelasi yang kuat dengan faktor tertentu saja [4].

\section{E. Regression Adjusted Control Chart}

Metode ini dikembangkan untuk merencanakan pengendalian secara univariat dari residual pada masingmasing variabel yang diperoleh [7]. Regression adjusted control chart dapat dilakukan apabila terdapat perbedaan variabel secara hierarki seperti variabel independen dan variabel dependen. Residual diperoleh dari hasil pengurangan antara nilai percobaan model regresi berganda dari masingmasing pengamatan sesuai pada y atau dengan persamaan sebagai berikut

$$
\varepsilon_{j}=y_{j}-\hat{y}_{j} .
$$

Model regresi dari variabel y dan $\mathrm{x}$ dapat mewakili proses yang ingin dikendalikan. Jika variabel respon yang digunakan lebih dari satu maka digunakan regresi multivariat dalam melakukan pemodelan untuk memperoleh nilai residual. Analisis regresi multivariat digunakan untuk menggambarkan hubungan antara lebih dari satu variabel respon dengan variabel prediktor dan diantara variabel respon terdapat hubungan. Model regresi multivariat yang terdiri dari $\mathrm{q}$ persamaan model linear secara simultan dapat ditunjukkan dalam bentuk matriks sebagai berikut

$$
\mathbf{Y}_{(n \times q)}=\mathbf{X}_{n \times(p+1)} \boldsymbol{\beta}_{(p+1) \times q}+\boldsymbol{\varepsilon}_{(n \times q)},
$$

dengan $E\left(\varepsilon_{i}\right)=0$ dan $\operatorname{Cov}\left(\varepsilon_{i}, \varepsilon_{i}\right)=\sigma_{i i} I$.

Untuk mendapatkan residual, langkah pertama yang harus dilakukan adalah dengan membuat model yang didapatkan dari melakukan estimasi parameter. Estimasi parameter dilakukan dengan rumus sebagai berikut [4].

$$
\hat{\boldsymbol{\beta}}=\left(\mathbf{X}^{T} \mathbf{X}\right)^{-1} \mathbf{X}^{T} \mathbf{Y} \text {. }
$$

Model regresi multivariat akan dikatakan sebagai model yang sesuai dan dapat digunakan untuk proses pengendalian apabila model tersebut telah memenuhi asumsi IIDN. Asumsi IIDN dalam analisis regresi yaitu asumsi residual identik (homogen), asumsi residual independen (saling bebas antara residual yang satu dengan yang lain), dan asumsi residual berdistribusi normal multivariat.

\section{F. Multivariate Exponentially Weighted Moving Covariance Matrix (MEWMC)}

Residual yang telah didapatkan dari proses regresi sebelumnya yaitu $\varepsilon_{j k} \sim N\left(\boldsymbol{\mu}_{0}, \boldsymbol{\Sigma}_{0}\right)$ dengan $j=1,2, \ldots, n$ dan $k=1,2, \ldots, p$. Penggunaan Multivariate Exponentially Weighted Moving Covariance Matrix (MEWMC) lebih mudah jika menggunakan vektor data yang telah distandarisasi. Oleh karena itu, dihitung matriks A menggunakan persamaan sebagai berikut

$$
\mathbf{A} \boldsymbol{\Sigma}_{\mathbf{0}} \mathbf{A}^{T}=\mathbf{I}_{\mathbf{p}} .
$$

Kemudian ditransformasi menggunakan rumus sebagai berikut

$$
\mathbf{U}_{\mathrm{j}}=\mathbf{A}\left(\boldsymbol{\varepsilon}_{\mathrm{j}}-\boldsymbol{\mu}_{\mathbf{0}}\right)
$$

Setiap elemen $\varepsilon_{j}$ adalah residual dari regresi $Y_{j}$ pada $X_{1}, X_{2}, \ldots, X_{p}$. Notasi $\mathbf{S}$ adalah standar untuk mastriks kovarians, dengan $\mathbf{S}_{\mathbf{0}}=\mathbf{I}_{\mathbf{p}}$, untuk $j=1,2, \ldots, n$ maka persamaan $\mathbf{S}_{j}$ adalah sebagai berikut

$$
\mathbf{S}_{j}=(1-\lambda) \mathbf{S}_{j-1}+\lambda \mathbf{U}_{j} \mathbf{U}_{j}^{\prime},
$$

dimana ketika proses terkendali, maka ekspektasi $E\left(\mathbf{S}_{j}\right)=\mathbf{I}_{\mathbf{p}}$. Statistik uji yang digunakan adalah sebagai berikut

$$
c_{j}=\operatorname{tr}\left(\mathbf{S}_{j}\right)-\log \left|\mathbf{S}_{j}\right|-p .
$$

Batas kendali $h$ dipilih berdasarkan nilai pembobot, Average Run Length (ARL), banyak dimensi dan panjang simulasi. Setelah didapatkan nilai $c_{j}$ dan $h$ maka diagram kendali dapat terbentuk dimana menampilkan plot $c_{j}$ terhadap $j$, dan menandakan out of control jika nilai $c_{j}>h[8]$.

\section{G. Proses Produksi Semen}

Proses produksi semen di PT "X" untuk menghasilkan semen melewati lima tahap yaitu proses penyiapan bahan baku, proses pengolahan bahan, proses pembakaran, proses penggilingan akhir, dan proses pengemasan. Kuat tekan semen berada pada tahap proses penggilingan akhir.

\section{METODOLOGI PENELITIAN}

\section{A. Sumber Data}

Penelitian ini menggunakan data sekunder yang didapatkan dari Departemen Quality Assurance PT "X". Data yang digunakan terdiri atas 320 data dengan 14 variabel prediktor dan 3 variabel respon.

\section{B. Variabel Penelitian}

Variabel penelitian yang digunakan pada penelitian ini adalah kualitas semen, dimana variabel dibagi menjadi dua yaitu variabel respon dan variabel prediktor. Berikut merupakan variabel yang akan digunakan dalam penelitian ini.

\begin{tabular}{clc}
\multicolumn{3}{c}{ Tabel 1. Variabel Penelitian } \\
\hline \hline \multicolumn{1}{c}{ Kariabel } & \multicolumn{1}{c}{ Keterangan } & Satuan \\
\hline \multicolumn{2}{c}{ Variabel Respon } & \\
$\mathrm{Y}_{1}$ & Kuat Tekan Semen 3 Hari & $\mathrm{kg} / \mathrm{cm}^{2}$ \\
$\mathrm{Y}_{2}$ & Kuat Tekan Semen 7 Hari & $\mathrm{kg} / \mathrm{cm}^{2}$ \\
$\mathrm{Y}_{3}$ & Kuat Tekan Semen 28 Hari & $\mathrm{kg} / \mathrm{cm}^{2}$ \\
\hline Variabel Prediktor & \\
$\mathrm{X}_{1}$ & Freelime (FCaO) & $\%$ \\
$\mathrm{X}_{2}$ & $\mathrm{C}_{3} \mathrm{~S}$ & $\%$ \\
$\mathrm{X}_{3}$ & $\mathrm{C}_{2} \mathrm{~S}$ & $\%$ \\
$\mathrm{X}_{4}$ & $\mathrm{C}_{3} \mathrm{~A}$ & $\%$ \\
$\mathrm{X}_{5}$ & $\mathrm{C}_{4} \mathrm{AF}$ & $\%$ \\
$\mathrm{X}_{6}$ & $\mathrm{MgO}$ & $\%$ \\
$\mathrm{X}_{7}$ & Blaine & $\mathrm{m}^{2} / \mathrm{kg}$ \\
$\mathrm{X}_{8}$ & $\mathrm{SO}$ & $\%$ \\
$\mathrm{X}_{9}$ & $\mathrm{Residu}_{3}$ 45 Mikron (R45) & $\%$ \\
$\mathrm{X}_{10}$ & Loss on Ignation (LOI) & $\%$ \\
$\mathrm{X}_{11}$ & $\mathrm{SiO}_{2}$ & $\%$ \\
$\mathrm{X}_{12}$ & $\mathrm{Al}_{2} \mathrm{O}_{3}$ & $\%$ \\
$\mathrm{X}_{13}$ & $\mathrm{Fe}_{2} \mathrm{O}_{3}$ & $\%$ \\
$\mathrm{X}_{14}$ & $\mathrm{CaO}$ & $\%$ \\
\hline \hline
\end{tabular}

\section{Langkah Analisis}

Langkah-langkah analisis pada penelitian ini adalah sebagai berikut.

1. Merumuskan masalah dan studi literature.

2. Mengumpulkan data.

3. Melakukan eksplorasi data untuk mengetahui karakteristik dari data semen.

4. Melakukan analisis faktor untuk mendapatkan variabel yang berpengaruh dominan terhadap kuat tekan semen. 
a. Melakukan pengujian distribusi normal multivariat untuk mengetahui apakah data dari variabel yang diamati telah mengikuti pola distribusi normal multivariat.

b. Melakukan pengujian kecukupan data menggunakan uji Kaiser-Meyer-Olkin (KMO) dan pengujian Bartlett antar variabel untuk mengetahui apakah data variabel kualitas semen saling berhubungan antar variabel.

c. Penentuan variabel kualitas semen (komposisi kimia dan sifat fisika dari semen) yang berpengaruh dominan terhadap kuat tekan semen.

5. Melakukan pengendalian kualitas statistik secara multivariat.

a. Mengendalikan kualitas semen dengan Regression Adjusted Control Charts untuk variabel hasil analisis faktor.

b. Melakukan pengujian asumsi residual untuk Regression Adjusted Control Charts untuk variabel hasil analisis faktor.

1. Pengujian asumsi residual identik.

2. Pengujian asumsi residual independen, apabila tidak memenuhi asumsi maka dilakukan deteksi outlier.

3. Pengujian asumsi residual berdistribusi normal multivariat, apabila tidak memenuhi asumsi maka dapat dilanjutkan karena diagram kendali MEWMC robust terhadap distribusi normal.

c. Residual yang diperoleh digunakan untuk pengendalian menggunakan diagram kendali Multivariate Exponentially Weighted Moving Covariance Matrix (MEWMC).

6. Menarik kesimpulan dan saran.

\section{HASIL DAN PEMBAHASAN}

\section{A. Karakteristik Kualitas Semen}

Karakteristik dari kualitas semen yang disajikan berupa ukuran pemusatan dan penyebaran data yaitu mean, median, nilai minimum dan maksimum serta varians. Berikut merupakan hasil statistika deskriptif dari variabel penyusun dan sifat semen yang digunakan.

Tabel 2. Deskripsi Karakteristik Kualitas

\begin{tabular}{|c|c|c|c|c|}
\hline Variabel & Mean & Varians & Minimum & Maksimum \\
\hline F-Lime & 1,098 & 0,059 & 0,550 & 2,060 \\
\hline $\mathrm{C}_{3} \mathrm{~S}$ & 49,039 & 6,560 & 41,900 & 60,390 \\
\hline $\mathrm{C}_{2} \mathrm{~S}$ & 16,111 & 5,647 & 5,010 & 22,500 \\
\hline $\mathrm{C}_{3} \mathrm{~A}$ & 7,746 & 0,513 & 5,730 & 9,460 \\
\hline $\mathrm{C}_{4} \mathrm{AF}$ & 9,497 & 0,096 & 8,610 & 10,270 \\
\hline $\mathrm{MgO}$ & 0,889 & 0,013 & 0,690 & 1,360 \\
\hline Blaine & 350,170 & 82,400 & 322,120 & 386,420 \\
\hline $\mathrm{SO}_{3}$ & 1,790 & 0,032 & 1,320 & 2,040 \\
\hline $45 \mu$ & 8,794 & 3,498 & 4,000 & 13,350 \\
\hline LOI & 4,115 & 0,232 & 2,580 & 4,910 \\
\hline $\mathrm{SiO}_{2}$ & 21,446 & 0,181 & 20,390 & 22,350 \\
\hline $\mathrm{Al}_{2} \mathrm{O}_{3}$ & 5,688 & 0,043 & 5,110 & 6,170 \\
\hline $\mathrm{Fe}_{2} \mathrm{O}_{3}$ & 3,025 & 0,024 & 2,560 & 3,290 \\
\hline $\mathrm{CaO}$ & 61,081 & 0,199 & 60,000 & 62,640 \\
\hline
\end{tabular}

Berdasarkan Tabel 2 dapat diketahui bahwa rata-rata, varians, minimum dan maksimum dari masing-masing variabel penyusun semen dan sifat fisika semen. Blaine merupakan variabel dengan nilai varians terbesar yaitu sebesar 82,40 dimana menunjukkan persebaran nilai hasil pengukuran terhadap rata-rata. Sedangkan, $\mathrm{MgO}$ merupakan variabel dengan nilai varians terkecil yaitu sebesar 0,01288 .

Tabel 3. Deskripsi Karakteristik Kuat Tekan Semen $\left(\mathrm{kg} / \mathrm{cm}^{2}\right)$

\begin{tabular}{lcccc}
\hline \hline \multicolumn{1}{c}{ Variabel } & Mean & Var & Min & Maks \\
\hline $\begin{array}{l}\text { Kuat Tekan } \\
\text { Semen 3 Hari }\end{array}$ & 203,120 & 174,220 & 163,000 & 240,000 \\
$\begin{array}{l}\text { Kuat Tekan } \\
\text { Semen 7 Hari }\end{array}$ & 269,380 & 297,710 & 230,000 & 319,000 \\
$\begin{array}{l}\text { Kuat Tekan } \\
\text { Semen 28 Hari }\end{array}$ & 360,990 & 531,970 & 302,000 & 424,000 \\
\hline \hline
\end{tabular}

Rata-rata dari kuat tekan 3 hari, 7 hari dan 28 hari masingmasing adalah sebesar 203,12 kg/ $\mathrm{cm}^{2} ; 269,38 \mathrm{~kg} / \mathrm{cm}^{2}$ dan $360,99 \mathrm{~kg} / \mathrm{cm}^{2}$. Sedangkan median dari masing-masing kuat tekan adalah $254 \mathrm{~kg} / \mathrm{cm}^{2} ; 323,5 \mathrm{~kg} / \mathrm{cm}^{2}$ dan $415 \mathrm{~kg} / \mathrm{cm}^{2}$. Data kuat tekan 3 hari, 7 hari dan 28 hari memiliki nilai varians masing-masing sebesar 174,22; 297,71 dan 531,97 yang menunjukkan persebaran nilai hasil pengukuran terhadap ratarata.

\section{B. Analisis Faktor terhadap Variabel Kualitas Semen}

Pada penelitian ini, variabel kualitas semen yang digunakan berjumlah empat belas variabel yang terdiri dari variabel komposisi kimia dan sifat fisika semen. Karena banyaknya variabel yang mempengaruhi kualitas semen baik secara kimia maupun fisika, digunakan analisis faktor untuk mendapatkan variabel yang berpengaruh terhadap kuat tekan semen. Terdapat beberapa asumsi yang harus dipenuhi untuk melakukan analisis faktor, yaitu uji normal multivariat, uji kecukupan data, dan uji Bartlett.

Pada pengujian normal multivariat, nilai korelasi antara $\mathrm{d}_{\mathrm{j}}{ }^{2}$ dan $\mathrm{q}_{\mathrm{j}}$ adalah 0,996 . Nilai tersebut kemudian dibandingan dengan critical point dari normal probability plot correlation coefficient (PPCC) distribution. Untuk nilai critical point dengan menggunakan alpha 5\% didapatkan critical point sebesar 0,9955. Nilai koefisien korelasi yang diperoleh lebih besar dari critical point, sehingga dapat disimpulkan bahwa data mengikuti distribusi normal multivariat.

Pengujian untuk identifikasi kecukupan data kualitas semen dilakukan dengan uji Kaiser-Mayer-Olkin (KMO). Data dikatakan memenuhi asumsi kecukupan data dan layak untuk difaktorkan jika nilai KMO lebih besar dari 0,5. Adapun hasil identifikasi kecukupan data menggunakan uji KMO didapatkan nilai KMO sebesar 0,490. Nilai KMO yang didapatkan kurang dari 0,5, sehingga dilakukan pemilihan variabel yang dimasukkan yaitu dengan menghilangkan variabel $\mathrm{FCaO}$ dari analisis. Variabel $\mathrm{FCaO}$ dihilangkan dari analisis karena nilai Measures of Sampling Adequacy (MSA) yang dimiliki variabel tersebut merupakan nilai yang paling kecil. Nilai MSA digunakan untuk mengetahui kecukupan data dan digunakan dalam menentukan sebuah variabel dapat dianalisis lebih lanjut atau tidak. Dimana jika nilai MSA > 0,5 maka variabel tersebut masih bisa diprediksi dan dapat dianalisis lebih lanjut. Setelah variabel $\mathrm{FCaO}$ dihilangkan dari analisis, dilakukan pengujian kecukupan data pada data kualitas semen yang baru. Didapatkan nilai KMO sebesar 0,527. Nilai KMO tersebut lebih besar dari 0,5. Sehingga dapat dinyatakan bahwa data kualitas semen telah memenuhi asumsi kecukupan data. 
Pada pengujian Bartlett didapatkan nilai $\chi_{\text {hitung }}^{2}$ sebesar 2974,516. Untuk nilai $\chi_{\left(\alpha ; \frac{1}{2} p(p-1)\right)}^{2}$ dengan menggunakan alpha 5\% dan derajat bebas sebesar 78 didapatkan sebesar 99,61693.

Nilai $\chi_{\text {hitung }}^{2}$ yang diperoleh lebih dari $\chi_{\left(\alpha ; \frac{1}{2} p(p-1)\right.}^{2}$. Selain itu, nilai signifikansi yang dihasilkan sebesar 0 lebih kecil dari $\alpha(0,05)$, sehingga keputusan yang dapat diambil adalah tolak $\mathrm{H}_{0}$. Oleh karena itu dapat disimpulkan bahwa matriks korelasi pada variabel bukan merupakan matriks identitas atau terdapat korelasi antar variabel yang digunakan.

Sebelum variabel penelitian dikelompokkan menjadi faktor, perlu dilakukan uji kecukupan data untuk setiap variabel, dimana variabel yang memiliki nilai $\mathrm{MSA}<0,5$ akan dihilangkan dari analisis. Variabel $\mathrm{C}_{2} \mathrm{~S}, \mathrm{C}_{3} \mathrm{~A}, \mathrm{MgO}$, Blaine, $\mathrm{SO}_{3}$, LOI, $\mathrm{SiO}_{2}, \mathrm{Al}_{2} \mathrm{O}_{3}$, dan $\mathrm{Fe}_{2} \mathrm{O}_{3}$ merupakan variabel yang terpilih dari empat belas variabel yang digunakan. Pada penelitian ini terdapat tiga faktor yang terbentuk dimana banyaknya faktor dipilih sesuai dengan banyaknya eigenvalue yang lebih dari satu. Selanjutnya dilihat dari nilai rotated component matrix untuk mengetahui pengelompokkan masing-masing variabel kedalam common faktor yang terbentuk. Rotasi faktor yang dipilih adalah dengan menggunakan prosedur varimax karena prosedur ini menghendaki varians yang maksimum dalam matriks faktor yang terbentuk, sehingga variabel dalam satu faktor memiliki korelasi yang cukup kuat. Hasil dari rotated component matrix yang diperoleh adalah sebagai berikut.

Tabel 4. Rotated Component Matrix

\begin{tabular}{lccc}
\hline \hline & \multicolumn{3}{c}{ Component } \\
\cline { 2 - 4 } & $\mathbf{1}$ & $\mathbf{2}$ & $\mathbf{3}$ \\
\hline $\mathrm{C}_{2} \mathrm{~S}$ & $-0,178$ & 0,541 & $\mathbf{0 , 6 0 8}$ \\
$\mathrm{C}_{3} \mathrm{~A}$ & $\mathbf{- 0 , 8 5 7}$ & 0,188 & 0,074 \\
$\mathrm{MgO}$ & 0,105 & $-0,346$ & $\mathbf{0 , 7 8 8}$ \\
Blaine & $\mathbf{0 , 5 9 3}$ & $-0,182$ & 0,232 \\
$\mathrm{SO}_{3}$ & 0,081 & $\mathbf{- 0 , 8 6 6}$ & 0,079 \\
$\mathrm{LOI}$ & $\mathbf{0 , 7 7 5}$ & $-0,085$ & $-0,223$ \\
$\mathrm{SiO}_{2}$ & $-0,236$ & $\mathbf{0 , 8 6 3}$ & $-0,127$ \\
$\mathrm{Al}_{2} \mathrm{O}_{3}$ & $\mathbf{- 0 , 8 2 2}$ & 0,267 & 0,087 \\
$\mathrm{Fe}_{2} \mathrm{O}_{3}$ & $\mathbf{0 , 8 0 9}$ & 0,051 & 0,243 \\
\hline \hline
\end{tabular}

Berdasarkan Tabel 4 dapat ditentukan kelompokkelompok variabel kedalam tiga kelompok faktor. Pengelompokkan ini berdasarkan nilai mutlak dari component terbesar masing-masing variabel, terletak pada faktor pertama, faktor kedua atau faktor ketiga. Hasil pada Tabel 4 menunjukkan bahwa variabel yang terpilih yaitu yang terdapat pada faktor 1 yaitu $\mathrm{C}_{3} \mathrm{~A}$, Blaine, LOI, $\mathrm{Al}_{2} \mathrm{O}_{3}, \mathrm{Fe}_{2} \mathrm{O}_{3}$.

\section{Monitoring Kuat Tekan Semen dengan Pendekatan Regression Adjusted}

Pengendalian kualitas dilakukan dengan pendekatan regression adjusted menggunakan regresi multivariat. Pada penelitian ini dilakukan pada variabel Kuat Tekan Semen 3 Hari $\left(\mathrm{Y}_{1}\right)$, Kuat Tekan Semen 7 Hari $\left(\mathrm{Y}_{2}\right)$, Kuat Tekan Semen 28 Hari $\left(\mathrm{Y}_{3}\right)$ dengan variabel hasil analisis faktor $\left(\mathrm{C}_{3} \mathrm{~A}\right.$, Blaine, LOI, $\mathrm{Al}_{2} \mathrm{O}_{3}, \mathrm{Fe}_{2} \mathrm{O}_{3}$ ).

Langkah awal dalam analisis regresi multivariat adalah mengestimasi parameter yang bertujuan untuk mendapatkan model. Model yang terbentuk setelah dilakukan estimasi parameter adalah sebagai berikut.

$$
\begin{aligned}
& Y_{1 j}=78,5-0,14 X_{1 j}+0,359 \mathrm{X}_{2 j}+0,66 \mathrm{X}_{3 j}-0,97 \mathrm{X}_{4 j}+0,92 \mathrm{X}_{5 j} \\
& Y_{2 j}=140,1-1,16 X_{1 j}+0,432 \mathrm{X}_{2 j}-6,22 \mathrm{X}_{3 j}-1,23 \mathrm{X}_{4 j}+0,48 \mathrm{X}_{5 j} \\
& Y_{3 j}=398,7+0,93 X_{1 j}+0,307 \mathrm{X}_{2 j}-13,18 \mathrm{X}_{3 j}-0,97 \mathrm{X}_{4 j}-14,9 \mathrm{X}_{5 j} \\
& \text { dengan } j=1,2, \ldots, n
\end{aligned}
$$

Setelah didapatkan model regresi dan residual, maka selanjutnya dilakukan pengujian asumsi residual yang telah didapatkan. Pengujian yang dilakukan ada tiga yaitu uji residual identik, uji residual independen dan uji residual berdistribusi normal multivariat. Pada hasil pengujian menggunakan Box's M didapatkan nilai signifikansi sebesar 0,371 yang lebih dari nilai $\alpha(0,05)$. maka dapat disimpulkan apabila matriks varians kovarians dari data residual hasil analisis regresi multivariat tersebut identik.

Dengan menggunakan plot macf diketahui bahwa pada ketiga residual terdapat lag yang keluar batas yaitu lag 1, 2, 3, $4,5,6$, dan 7 pada residual 1 dan residual 3, lag $1,2,3,4,5,6$, 7,8 dan 10 pada residual 2. Artinya pada ketiga residual terjadi autocorrelation dengan dirinya sendiri. Pada kasus ketiga residual ini, asumsi residual independen tidak terpenuhi karena terdapat autocorrelation sehingga perlu dilakukan deteksi outlier untuk mengetahui apakah didalam data residual terdapat outlier. Berikut ini merupakan boxplot residual.

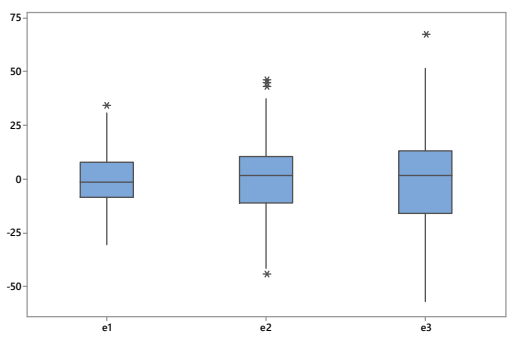

Gambar 1. Boxplot Residual

Gambar 1 merupakan boxplot untuk ketiga residual. Pada residual 1 dan 3 terdapat satu data residual yang terjadi outlier, pada residual 2 terdapat tiga data residual yang terjadi outlier. Hal tersebut mengindikasikan bahwa penyebab asumsi residual independen tidak terpenuhi adalah adanya data outlier. Oleh karena itu, langkah selanjutnya dilakukan pengendalian kualitas dengan menggunakan diagram kendali MEWMC.

Pada pengujian normal multivariat didapatkan nilai korelasi antara $\mathrm{d}_{\mathrm{j}}^{2}$ dan $\mathrm{q}_{\mathrm{j}}$ adalah sebesar 0.9931. Nilai tersebut kurang dari critical point dari normal probability plot correlation coefficient (PPCC) distribution yaitu 0,9955, sehingga dapat disimpulkan bahwa residual tidak mengikuti distribusi normal multivariat. Pada penelitian ini digunakan diagram kendali MEWMC yang robust terhadap distribusi tidak normal multivariat, sehingga analisis dapat dilanjutkan.

\section{Pengendalian Kualitas Semen dengan Diagram Kendali $M E W M C$}

Pengendalian kualitas semen pada penelitian ini dilakukan dengan menggunakan dua fase. Fase satu dilakukan untuk mendapatkan nilai pembobot yang optimum. Sedangkan fase dua dilakukan untuk monitoring kualitas semen pada saat terjadi permintaan produksi ALM rendah untuk kemudahan pembakaran yang kemudian ALM dinaikkan kembali untuk menghemat pemakaian iron sand $(\mathrm{Fe})$.

\section{Fase Satu}

Untuk mengendalikan variabilitas proses fase satu dilakukan dengan menggunakan diagram kendali 
MEWMC pada data residual ke-1 hingga ke-255. Pengendalian variabilitas proses fase satu dilakukan untuk mendapatkan nilai pembobot yang optimum. Selanjutnya, pembobot yang telah optimum digunakan untuk monitoring proses pada fase dua. Dalam penelitian ini digunakan nilai pembobot $\lambda$ yaitu $0,1,0,2$ dan 0,3 yang dipilih karena lebih direkomendasikan daripada menggunakan nilai pembobot besar yang dapat memberikan hasil yang bias [8]. $\mathrm{C}_{j}$ merupakan statistik uji dari diagram kendali MEWMC. Batas kendali $h$ didapatkan dengan menggunakan program yang telah disediakan untuk diagram kendali MEWMC dengan menggunakan masing-masing lambda, ARL sebesar 370, $p$ yang merupakan jumlah dimensi yaitu 3, dan jumlah simulasi yaitu 1000. Setelah didapatkan $\mathrm{Cj}$ dan batas kendali, maka diperoleh diagram kendali MEWMC.

Berikut merupakan pengendalian variabilitas proses pada fase satu.

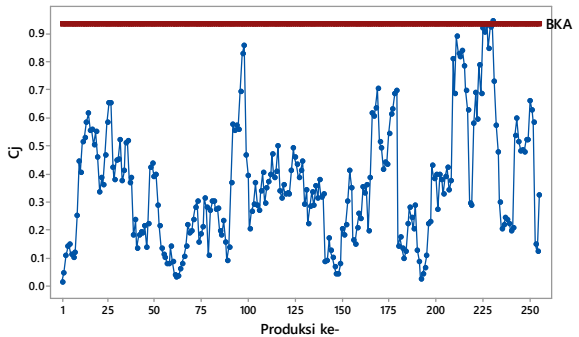

Gambar 3. Diagram Kendali MEWMC Fase Satu dengan $\lambda=0,1$

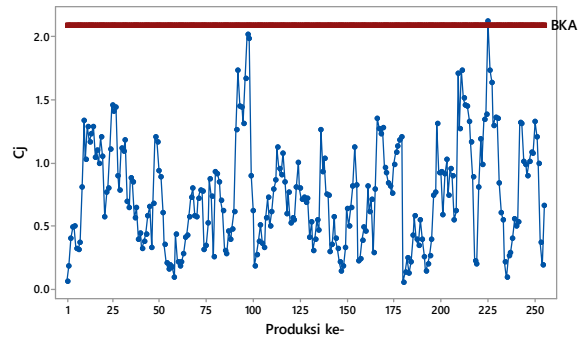

Gambar 4. Diagram Kendali MEWMC Fase Satu dengan $\lambda=0,2$

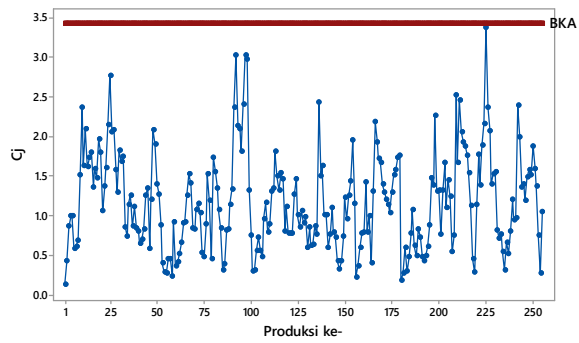

Gambar 5. Diagram Kendali MEWMC Fase Satu dengan $\lambda=0,3$

Untuk mendapatkan nilai pembobot yang paling optimum dalam mendeteksi adanya data produksi yang out of control yang menunjukkan error paling kecil, dihitung selisih yang paling minimum dari $|\operatorname{Max}(\mathrm{C} j)-\mathrm{h}|$. Berikut adalah hasil perhitungan untuk menentukan pembobot yang paling optimum.

Tabel 5. Hasil Perhitungan Nilai $|\operatorname{Max}(C j)-\mathrm{h}|$ untuk MEWMC

\begin{tabular}{cccc}
\hline$\lambda$ & $\operatorname{Max}(\boldsymbol{C})$ & $\mathbf{h}$ & $|\mathbf{M a x}(\boldsymbol{C j})-\mathbf{h}|$ \\
\hline $\mathbf{0 , 1}$ & $\mathbf{0 , 9 4 2 8}$ & $\mathbf{0 , 9 3 4 0}$ & $\mathbf{0 , 0 0 8 8}$ \\
$\mathbf{0 , 2}$ & 2,1170 & 2,0881 & 0,0289 \\
$\mathbf{0 , 3}$ & 3,3668 & 3,4173 & 0,0505
\end{tabular}

Berdasarkan Tabel 5 dapat dilihat pada pengendalian variabilitas proses menggunakan pembobot $\lambda=0,1$ yang ditunjukkan oleh Gambar 3 memiliki nilai $|\operatorname{Max}(C j)-\mathrm{h}|$ yang paling kecil sehingga dipilih sebagai pembobot yang paling optimum untuk diagram kendali MEWMC.

Untuk nilai pemboboot $\lambda=0,1$ dapat dilihat pada Gambar 3 bahwa masih terdapat 1 data produksi yang berada di luar batas kendali yaitu produksi ke-230. Titik yang keluar dari batas kendali harus dicari penyebabnya terlebih dahulu. Setelah diperiksa secara teknis pada produksi ke-230 terjadi peristiwa dimana ALM (Alumina Modulus) tidak positif terhadap kuat tekan semen. Selanjutnya, titik out of control tersebut dapat dibuang sampai dengan semua produksi in control, sehingga didapatkan seperti Gambar 6 dimana sudah tidak terdapat titik yang berada di luar batas kendali.

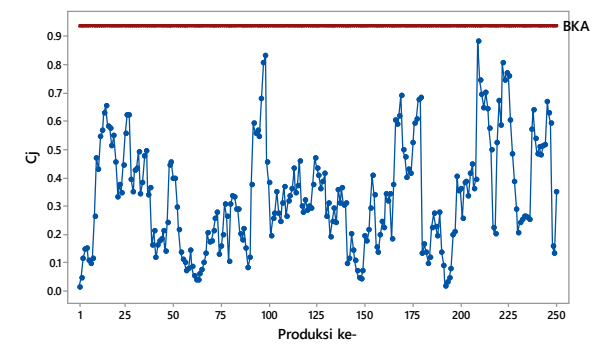

Gambar 6. Diagram Kendali MEWMC Fase Satu Perbaikan $(\lambda=0,1)$

\section{Fase Dua}

Setelah pengendalian pada fase satu selesai, dilakukan pengendalian variabilitas proses pada fase dua yang bertujuan untuk memonitoring proses produksi pada data produksi ke-256 sampai dengan data produksi ke-320. Dimana, pada data produksi tersebut terjadi permintaan produksi ALM rendah untuk kemudahan pembakaran yang kemudian ALM dinaikkan kembali untuk menghemat pemakaian iron sand (Fe). Nilai pembobot yang digunakan pada fase dua adalah nilai pembobot pada fase satu yang optimum. Pada fase satu didapatkan nilai pembobot optimum $\lambda=0,1$ yang digunakan untuk mengendalikan variabilitas pada fase dua sebagai berikut.

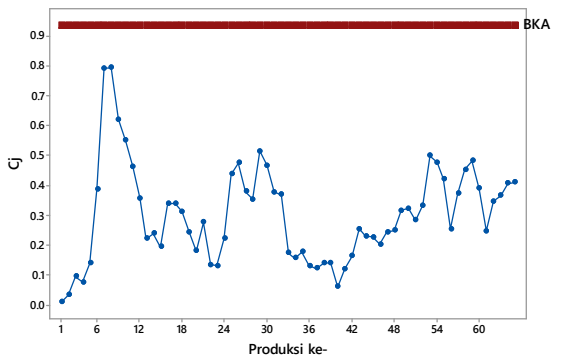

Gambar 7. Diagram Kendali MEWMC Fase Dua

Nilai pembobot $\lambda=0,1$ dengan batas kendali 0,9340 yang ditunjukkan seperti Gambar 7 dapat disimpulkan bahwa pengendalian variabilitas proses untuk fase dua terkendali secara statistik, karena pada plot $\mathrm{Cj}$ tidak ada titik yang berada di luar batas kendali.

\section{KESIMPULAN DAN SARAN}

Berdasarkan hasil analisis dan pembahasan didapatkan bahwa variabel yang berpengaruh dominan terhadap kuat tekan semen menggunakan analisis faktor yaitu $\mathrm{Al}_{2} \mathrm{O}_{3}, \mathrm{Fe}_{2} \mathrm{O}_{3}$, $\mathrm{C}_{3} \mathrm{~A}$, Blaine dan LOI. Pengendalian kuat tekan semen 
menggunakan diagram kendali MEWMC based on Regression Adjusted Variables pada variabel hasil analisis faktor. Pada fase satu didapatkan bahwa dengan menggunakan $\lambda$ sebesar 0,1 dan 0,2 menghasilkan proses yang belum terkendali secara statistik. Sedangkan dengan menggunakan $\lambda$ sebesar 0,3 menghasilkan proses terkendali secara statistik. Hasil pengendalian variabilitas menggunakan diagram kendali MEWMC didapatkan bahwa nilai pembobot optimum yang digunakan yaitu $\lambda=0,1$ yang menghasilkan bahwa telah terkendali secara statistik yang berarti bahwa tidak terjadi pergeseran proses.

Saran yang diberikan kepada Departemen Quality Assurance PT "X" adalah perlu mempertimbangkan dan melakukan perbaikan proses pengendalian kualitas karena dalam proses produksi masih terdapat data out of control pada fase satu. Selain itu, perlu dilakukan pemeriksaan terhadap komposisi kimia dan sifat fisika semen yang digunakan karena secara teknis dan statistik hasil variabel yang berpengaruh dominan terhadap kuat tekan semen memiliki perbedaan.

Sedangkan saran untuk penelitian selanjutnya adalah sebaiknya menggunakan regression asjusted dengan mengatasi adanya multikolinieritas sehingga dapat menghasilkan model yang lebih baik. Selain itu, dapat menggunakan beberapa metode lain sehingga didapatkan metode yang paling baik untuk pengendalian kualitas dan dapat menjadi pertimbangan bagi perusahaan.

\section{DAFTAR PUSTAKA}

[1] V. D. Gemert, L. Czarnecki, P. Lukowski and E. Krapen, Cement Concrete and Concrete Polymer Composites, Brussels: Catholic Universiti Leuven, 2004.

[2] M. A. Ashari, "Monitoring Variabilitas Proses dan Mean Proses Tahap Penggilingan Akhir Produk Semen Ordinary Portland Cement (OPC) di PT Semen Indonesia (Persero) Tbk," ITS Surabaya, 2017.

[3] A. C. Putri, "Penerapan Diagram Kontrol Multivariat Regression Adjusted pada Proses Penggilingan Akhir Produk Semen PPC di PT Semen Indonesia (Persero) Tbk," ITS Surabaya, 2017.

[4] R. A. Johnson and D. W. Wichern, Applied Multivariate Statistical Analysis Sixth Edition, New Jersey: Prentice Hall, 2007.

[5] A. Field, Discovering Statistics Using IBM SPSS Statistics, 4th Revised edition ed., London, United Kingdom: Sage Publications Ltd, 2013.

[6] D. F. Morrison, Multivariate Statistical Methods, Fourth Edition ed., USA: McGraw-Hill, Inc., 2005.

[7] D. M. Hawkins, "Multivariate quality control based on regression-adjusted variables," Technometrics, vol. 33, pp. 6175, 1991.

[8] D. M. Hawkins and E. M. Maboudou-Tchao, "Multivariate Exponentially Weighted Moving Covariance Matrix," Technometrics, pp. 55-166, 2008. 